る.紫外線照射により $\varepsilon^{\prime}$ が減り， $\varepsilon^{\prime \prime}$ がかなり増大す る.これに対する一つの可能な説明は, 非架橋酸素イオ ンが架橋イオンに変わるため, 網目構造の連結度が増 し，その固有振動の周波数が 低下したので， $10^{6} \mathrm{~Hz}$ 以 上の高周波域にある変形損失のピーク位置が低周波側へ ずれ，ピークの裾が $10^{6} \mathrm{~Hz}$ 以下の周波域一現われたと いうものである. $10^{6} \mathrm{~Hz}$ 付近では, 網目変形の振動形態 の一部は，交流電界に追いつかなくなり，向 几寄与しな くなるため, 泉が減る。
われわれのガラス試料の誘電特性を測定し，また結果につい て貴重な見解を示された電気試験所並河洋氏に深く謝意を表す。

\section{文献}

1）大岡一夫, 岸井貫, 䆛協 76 [1] 6 (1968).

2) 同上, 同 76 [9] 305 (1968).

3）並河洋, 熊田虔, 同 76 [3] 64 (1968).

4) A.E. Owen, "Progress in Ceramic Science" Volume 3 (1963), p. 155. Published by Pergamon Press.

$(10 / 27 / 1969$ 受付 $)$

\title{
Thermal Expansion of Arsenic-Sulfur Glasses
}

\author{
By \\ Yoji KAWAMOTO and Shoji TSUCHIHASHI \\ (Department of Chemistry, Faculty of Science, Kobe University, Rokkodai, Kobe)
}

\section{As-S 系ガラスの 熱膨 脹 \\ 河 本 洋 二・土 橋 正 二 \\ (神戸大学理学部)}

Some properties and the structure of the glasses in the system As-S have previously been reported $^{1) \sim 3}$.

However its thermal properties have not been studied yet. The purpose of this note is to report the thermal expansion of the As-S glasses and how the result can be explained with the structural models for the As-S glasses described in the previous paper ${ }^{33}$.

The composition of glasses chosen for study are as follows, $\mathrm{As}_{2} \mathrm{~S}_{2.7}, \mathrm{As}_{2} \mathrm{~S}_{2.85}, \mathrm{As}_{2} \mathrm{~S}_{3}, \mathrm{As}_{2} \mathrm{~S}_{4}$, $\mathrm{As}_{2} \mathrm{~S}_{6}, \mathrm{As}_{2} \mathrm{~S}_{7}, \mathrm{As}_{2} \mathrm{~S}_{9}, \mathrm{As}_{2} \mathrm{~S}_{12}$. The glasses were prepared by melting together high purity elements in evacuated, sealed Pyrex tubes which were placed in a rocking furnace at $600^{\circ} \mathrm{C}$ for several hours.

A tube-type vitreous-silica dilatometer and differential gaging electronic comparator were used to measure the thermal expansion and the softening temperature $\left(A_{t}\right)$, transformation temperature $\left(T_{g}\right)$ and linear coefficients of thermal expansion from room temperature to $T_{g}$ and $T_{g}$ to $A_{t}\left(\alpha_{1}\right.$ and $\alpha_{h}$, respectively) were determined from the expansion curves.

Before the measurement the specimen, a bar of about $(3-4) \times(3-4) \times(20-25) \mathrm{mm}$, was annealed at near the transformation temperature for one hour and cooled gradually to room temperature in the furnace. The heating rate in the measure- ment was controlled to be about $2^{\circ} \mathrm{C} / \mathrm{min}$. The results are shown in Fig. 1 and 2.

As can be seen from the figures, each value does not change linearly in proportion to $\mathrm{S}$ content but maxima in $T_{g}$ and $A_{t}$ and minimum in $\alpha_{k}$ were observed on the point of $\mathrm{As}_{2} \mathrm{~S}_{3}$. These phe nomena can be interpreted qualitatively as follows.

According to the structural informations for the As-S glasses previously reported ${ }^{3)}$, -Ás-S-Aslinkages are replaced with $-\mathrm{As}^{\prime}-(\mathrm{S})_{n}-\mathrm{As}^{\prime}-$ linkages with increasing $\mathrm{S}$ content above $\mathrm{As}_{2} \mathrm{~S}_{3}$ and the structure of glass approaches to that of plastic $S$ with further addition of $S$. On the other hand $S$ in -As-S-As- linkages is eliminated and -As-A'sbonds are formed with decreasing $S$ content below $\mathrm{As}_{2} \mathrm{~S}_{3}$. While the bond strengths of both $\mathrm{S}-\mathrm{S}$ bond $(33.4 \pm 4.8 \mathrm{kcal} / \mathrm{mole})$ and As-As bond (32.1 $\mathrm{kcal} / \mathrm{mole}$ ) are considerably lower than that of As-S bond $(61 \mathrm{kcal} / \mathrm{mole})$. Therefore $T_{g}$ and $A_{t}$ show the maxima in $\mathrm{As}_{2} \mathrm{~S}_{3}$ composition and their values decrease as the $S$ content increases or decreases.

The increase in $\alpha_{1}$ with an increase of $\mathrm{S}$ content above $\mathrm{As}_{2} \mathrm{~S}_{3}$ is probably attributed to that $\mathrm{S}$ has large thermal coefficient of linear expansion. However with decreasing $\mathrm{S}$ content below $\mathrm{As}_{2} \mathrm{~S}_{3}$ $\alpha_{1}$ is found to increase again. 
For this phenomenon the following interpretation may be considered. With decreasing $\mathrm{S}$ content below $\mathrm{As}_{2} \mathrm{~S}_{3},-\mathrm{A}^{\prime} \mathrm{s}-\mathrm{As}^{\prime}-$ bonds are formed in the glass network and this causes the deformation of layer structure and at the same time the expansion of interlayer distance. Consequently it becomes easy for the glasses with lower $\mathrm{S}$ content than that of $\mathrm{As}_{2} \mathrm{~S}_{3}$ to expand thermally.

The relationships of composition and $A_{t}, T_{g}, \alpha_{1}$ or $\alpha_{h}$ have already been reported over the glass forming region of the As-S system ${ }^{5}$. However between the present work and that by Tanaka et al. there is an essential discrepancy in the composition range of lower $\mathrm{S}$ content than that of $\mathrm{As}_{2} \mathrm{~S}_{3}$. This could be attributed to the structural difference of glasses depending on the glass preparation because in the case of Tanaka et al. the glass specimens are prepared by the distillation method.

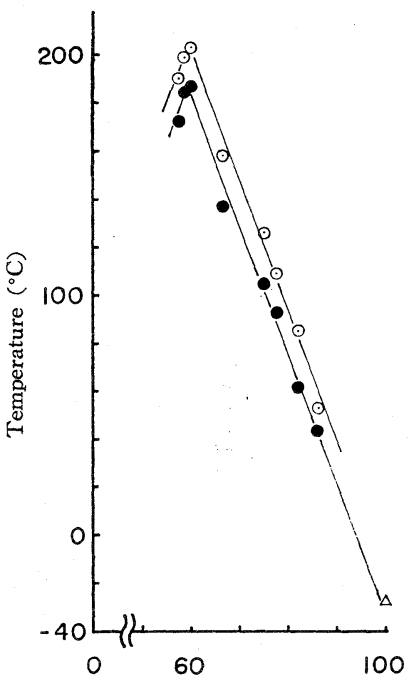

Atomic \% S

Fig. 1. $T_{g}(\bigcirc)$ and $A_{t}(\bigcirc)$ of As-S glasses and $T_{g}$ $(\triangle)$ of plastic $\mathrm{S}^{4}$.

2) S. Tsuchihashi, Y. Kawamoto, and K. Adachi, ibid. 76 [4] 101-06 (1968).

3) S. Tsuchihashi and Y. Kawamoto, ibid. 77 [2] 35-39 (1969).

4) A. Tobolsky, G.D.T. Owen and A. Eisenberg, J. Colloid Sci. 17, 717-25 (1962).

5) M. Tanaka, T. Minami, and M. Hattori, Japan. J. appl. Phys. 5, 185-86 (1966)

6) S. Maruno, ibid. 7, 1434-39 (1968).

[Received Jan. 19, 1970]

1) S. Tsuchihashi, T. Yano, T. Komatsu, and K. Adachi, Yogyo-Kyokai-Shi 74 [11] 353-61 (1966).

\title{
The Thermal Conductivity of Aluminum Nitride
}

\author{
By \\ Takaho TANAKA* and Hiroshige SUZUKI* \\ (* National Institute for Reseaches in Inorganic Materials, Tokyo)
}

\section{窒化アルミニウムの熱伝導度 \\ 田中高穂・鈴 木弘茂 (科学技術庁無機材質研究所)}

The thermal conductivity of aluminum nitride samples was measured from $1250^{\circ} \mathrm{C}$ to $1630^{\circ} \mathrm{C}$ on electron beam method ${ }^{1) \sim 3}$.

The thermal diffusivity $\kappa$ was calculated from measured phase difference of the temperature fluctuations between two faces of the slab, and according to Wheeler's equation of first approximation,

$$
\kappa=\frac{2.9 l^{2} \omega}{2 \pi \Delta \theta}
$$

where $\omega$ is the modulation frequency of electron beam, $l$ is the thickness of the slab and $\Delta \theta$ is 